\title{
Prophylactic Surgery for Multiple Endocrine Neoplasia Type IIa after Genetic Diagnosis: Is Parathyroid Transplantation Indicated?
}

\author{
Ruth A. Decker, M.D., ${ }^{1}$ James D. Geiger, M.D., ${ }^{2}$ Charles E. Cox, M.D., ${ }^{2}$ Marilyn Mackovjak, B.S.N., ${ }^{1}$ \\ Minakshi Sarkar, B.S., ${ }^{1}$ Michael L. Peacock, B.S. ${ }^{1}$ \\ ${ }^{1}$ Department of Surgery, Division of Endocrine Surgery, University of Michigan Medical Center, Ann Arbor, Michigan 48109-0331, U.S.A. \\ ${ }^{2}$ Department of Pediatric Surgery, University of Michigan Medical Center, Ann Arbor, Michigan 48109-0331, U.S.A.
}

\begin{abstract}
Identification of germline mutations in the RET proto-oncogene predisposing to multiple endocrine neoplasia type IIa (MEN-IIa) has allowed a DNA-based approach to diagnosis and treatment by prophylactic thyroidectomy in children testing genetically positive. Although total thyroidectomy is the accepted operation for $\mathrm{C}$ cell disease, the necessity of routine total parathyroidectomy and autotransplantation as previously described in these asymptomatic children is questionable, particularly given the low occurrence of hyperparathyroidism in MEN-IIa (10-20\%). Thirty-six children (ages 1 month to 12 years) from four MEN-IIa kindreds at risk for disease underwent genetic testing. Mutational analysis was done using a highly sensitive PCR-based denaturing gradient gel electrophoresis technique. Parathyroid or serum calcium concentrations were determined preoperatively. Of the 36 children at risk, 18 were found to have a MEN-IIa mutation; 11 have undergone prophylactic thyroidectomy at ages ranging from 2 to 12 years (mean 7.5 years). In each case, there was no biochemical evidence of hypercalcemia preoperatively, and all parathyroid glands were identified and were found to be grossly normal at exploration. Glands were carefully dissected and left in situ. Postoperatively, 10 of the 11 children maintained normocalcemia, allowing discharge within 24 to 36 hours. Resected thyroid glands contained $\mathrm{C}$ cell hyperplasia in nine, medullary carcinoma in one, and normal histology in one. We conclude that an alternative to routine parathyroidectomy may be desirable for prophylactic treatment of MENIIa. In situ parathyroid preservation can be safely achieved without compromising the completeness of the thyroid resection. This conservative approach obviates the potential morbidity associated with total parathyroidectomy and autotransplantation.
\end{abstract}

Germline missense mutations responsible for hereditary medullary thyroid carcinoma (MTC) in the autosomal dominant cancer syndromes, multiple endocrine neoplasia type IIa (MEN-IIa) and familial medullary thyroid carcinoma (FMTC) have been identified within the coding region of the RET proto-oncogene, a putative receptor tyrosine kinase $[1,2]$. Penetrance of MTC in MEN-IIa is essentially $100 \%$, whereas expression of adrenal gland pheochromocytoma and hyperparathyroidism (HPT) is more variable, and congenital aganglionosis (Hirschsprung's disease) is a rare event [3, 4]. FMTC, a phenotypic variant of MEN-IIa, is characterized by MTC alone. To date, the described mutations predisposing to MEN-IIa involve single base changes at one of six

Correspondence to: R.A. Decker, M.D., 7536 Forsythe Boulevard, Suite 91, St. Louis, Missouri 63105, U.S.A. highly conserved cysteines within the extracellular domain of RET at codons 609, 611, 618, 620, and 634 within exons 10 and 11 [1, 2, 5-7]. More recently, missense mutations affecting the tyrosine catalytic domain in RET exons 13 and 14 at codons 768 and 804 have been reported to segregate with disease in several FMTC kindreds [8, 9]. Overall, RET mutations have been identified in approximately $97 \%$ of patients with MEN-IIa and $86 \%$ of FMTC kindreds [10].

Identification of the genetic alterations predisposing to MENIIa has allowed a DNA-based strategy for direct mutation detection and diagnosis in patients at risk [11]. The value of this approach is readily apparent. Previously, screening for occult hereditary MTC was accomplished biochemically by detecting an elevation in the basal or pentagastrin-stimulated calcitonin concentration. This approach, although highly sensitive, had several limitations. First, due to age-dependent biochemical penetrance of the $\mathrm{C}$ cell abnormality, annual testing until 30 years of age was necessary to safely exclude an affected status. Second, unpleasant side effects produced by the pentagastrin injection and high cost of the calcitonin assaying hindered compliance with family evaluation. Furthermore, calcitonin screening of all first-degree relatives in index MTC cases was cumbersome and difficult to accomplish. Finally, as we have shown, calcitonin testing appears to lack specificity with exaggerated responses occurring in normal subjects [11]. This has led in the past to unnecessary thyroid operations and disease surveillance. In contrast, diagnosis of MEN-IIa and FMTC by direct mutation detection is highly sensitive, absolutely specific, and definitive. Therefore genetic screening need only be performed on a single occasion to determine susceptibility to MEN-IIa/FMTC with adverse effects confined to that of a simple peripheral blood draw.

Because MTC is essentially $100 \%$ penetrant in MEN-IIa, prophylactic total thyroidectomy is the accepted operation in children testing genetically positive and, given the natural history of the disease, can be readily justified despite normal calcitonin findings. A recent study has also described the routine use of total parathyroidectomy and forearm autotransplantation in asymptomatic children with genetically proved MEN-IIa [12]. However, a more conservative and alternative approach such as in situ parathyroid gland preservation in these young patients with- 
out evidence of hyperparathyroidism might be considered for three reasons. First, unlike the adrenal chromaffin and thyroid $\mathrm{C}$ cell abnormalities, the incidence of parathyroid disease in MENIIa is low, occurring in only approximately $10 \%$ to $20 \%$ of patients $[13,14]$. Second, the parathyroid gland involvement in MEN-IIa, if present, has been shown not to be multifocal [3, 13, 14]. Finally, recent MEN-IIa phenotype-genotype correlation studies suggest that predisposition to hyperparathyroidism is not uniform among the MEN-IIa RET mutations; rather, it is most tightly linked to the CGCArg mutation at codon 634 in exon 11 [10]. Therefore aggressive resection of all four parathyroid glands appears unnecessary in most cases. The purpose of this report is to describe our success with an alternative, less radical approach to the operative management of MEN-IIa following DNA diagnosis that can be considered for children undergoing prophylactic treatment.

\section{Patients and Methods}

\section{Patient Population}

Fifteen male and 21 female patients (ages 1 month to 12 years) from four distinct, well characterized, multigenerational MEN-IIa kindreds at direct risk for disease underwent mutational analysis. Two of the four kindreds from which eight of the children are derived have been previously described by our group in greater detail $[3,15]$. The risk of MEN-IIa in each child was recognized following genetic and histologic confirmation of an affected status in a parent. Informed parental consent was obtained prior to blood sampling and mutational analysis in each case.

\section{Mutational Analysis of RET Exons 10 and 11}

Polymerase chain reaction (PCR) amplification of RET exons 10 and 11 and denaturing gradient gel electrophoresis (DGGE) was performed on genomic DNA extracted from the peripheral blood leukocytes using established experimental conditions developed in our laboratory [16]. Independent blood sampling was performed in each case on two occasions. Primers 5'GCGCCCCCCGCCCCCGCCCCGCCCGCCGCGGCGCCCCAGGAGGTGAGTG 3' (5' primer) and 5'CGTGGTGGTCCCGGCCGCC3' ( $3^{\prime}$ primer) were selected from intronic sequence flanking the intron/exon boundaries of exon 10 following MELT87 analysis [17]. Amplification of the 216 basepair (bp) fragment was performed using $1 \mu \mathrm{g}$ genomic DNA template, $2.2 \mu \mathrm{M}$ each oligonucleotide primer, $200 \mu \mathrm{M}$ each dNTP, $1.25 \mathrm{U}$ Taq DNA polymerase (Gibco BRL, Gaithersburg, MD, USA). $10 \mathrm{mM}$ Tris ( $\mathrm{pH} 8.3$ ), $50 \mathrm{mM} \mathrm{KCl}, 2.0 \mathrm{mM} \mathrm{MgCl}$ in a total volume of $50 \mu \mathrm{l}$. Thermal cycling conditions consisted of 35 cycles at $95^{\circ} \mathrm{C}$ for 1 minute (denaturation) and at $72^{\circ} \mathrm{C}$ for 1 minute (annealing and extension).

Exon 11 primers, 5' CCTCACACCACCCCCACCCA3' (5' primer) and 5'(GC)15GTCCAGCGAGGGCCGGCGGG3' (3' primer) flanking Cys codon 634 were chosen following MELT87 analysis. Amplification was performed using $1 \mu \mathrm{g}$ genomic DNA, $2.2 \mu \mathrm{M}$ each primer, $200 \mu \mathrm{M}$ dNTP, 1.25 units Taq polymerase, 10 $\mathrm{mM}$ Tris ( $\mathrm{pH} 8.3$ ), $50 \mathrm{mM} \mathrm{KCl}, 1.5 \mathrm{mM} \mathrm{MgCl}_{2}$, and $10 \% \mathrm{DMSO}$ in a final volume of $50 \mu \mathrm{l}$. Expected product size is $268 \mathrm{bp}$. Conditions for amplification consisted of 35 cycles of denaturation at $95^{\circ} \mathrm{C}$ for 1 minute (denaturation), annealing at $62^{\circ} \mathrm{C}$ for 30 seconds, and extension at $72^{\circ} \mathrm{C}$ for 1 minute. Following each amplification, samples were heated to $100^{\circ} \mathrm{C}$ for 10 minutes and allowed to cool to room temperature prior to gel loading to facilitate heteroduplex formation.

The DGGE analysis was carried out on a $1 \mathrm{~mm}$ thick $9 \%$ acrylamide gel (acrylamide:bis-acrylamide 20:1) with a $50 \%$ to $80 \%$ linear gradient of denaturants $(100 \%=7 \mathrm{M}$ urea, $40 \%(\mathrm{v} / \mathrm{v})$ formamide) in $1 \times$ TAE buffer ( $40 \mathrm{mM}$ Tris acetate, $20 \mathrm{mM}$ sodium acetate, $1 \mathrm{mM}$ EDTA at $\mathrm{pH} 7.8$ ). Gel was overlayed with a $6 \%$ polyacrylamide stacker (acrylamide:bis-acrylamide 30:1) containing $1 \times$ TAE. Amplified PCR fragments were electrophoresed at $65^{\circ} \mathrm{C}$ and $17 \mathrm{~mA} /$ gel for 18 hours (Hoefer Scientific Instruments, San Francisco, CA, USA), with recirculation of buffer from the lower to the upper electrode chamber, and ethidium bromide-stained (10 minutes) prior to visualization. Per laboratory protocol, initial genetic testing results are routinely confirmed by a second, identical analysis.

\section{Physical Examination and Biochemical Studies}

Examination of the neck in the 36 children was unremarkable. All children testing genetically positive scheduled for immediate thyroidectomy were evaluated biochemically for asymptomatic hyperparathyroidism with parathyroid hormone (intact), serum calcium determinations, or both preoperatively. Fasting baseline calcitonin sampling was considered optional and was performed in only 8 of the 11 children. To date, 6 of the 11 children have undergone pentagastrin stimulation testing immediately following thyroidectomy. Provocative testing consisted of the intravenous administration of a pulse injection of pentagastrin (Peptavlon, Ayerst, NY, USA) at the conventional dose of $0.5 \mu \mathrm{g} / \mathrm{kg}$. Patients were evaluated in the fasting state, and blood was collected from an antecubital vein before and at 1,2, and 5 minutes after the test agent was administered. Calcitonin levels were determined using a commercially available radioimmunoassay (Nichols Institute, San Juan Capistrano, CA, USA). Postoperative serum calcium levels were routinely documented the evening and morning after thyroidectomy.

\section{Results}

Genetic, biochemical, and histologic findings for each child are summarized in Table 1.

\section{DNA Analysis of RET}

Of the 36 children at risk for disease, 18 were found to have a MEN-IIa mutation. Of the 18, 11 (age range 2-12 years; mean 7.5) found to be genetically positive underwent immediate thyroidectomy. Within the group of 11 children undergoing immediate operative treatment, DGGE identified an abnormal multiple banding pattern in exon 10 of the RET proto-oncogene in all cases. Germline RET mutations consistent with MEN-IIa were detected at Cys codons 618 (TGC $\rightarrow$ AGC) and 620 (TGC $\rightarrow$ CGC, TGC $\rightarrow$ TGG) and confirmed by direct DNA sequencing (Fig. 1). An example of the DGGE analysis of a MEN-IIa kindred with the Cys codon 620 TGG mutation is shown in Figure 2. The multiple banding pattern reflective of a heterozygous missense change is clearly present in all family members affected with the disease. Unaffected individuals exhibit a single band resulting from normal homozygous sequence. 
Table 1. Children undergoing prophylactic thyroidectomy after RET mutational analysis by DGGE.

\begin{tabular}{|c|c|c|c|c|c|c|}
\hline $\begin{array}{l}\text { Pt no./ } \\
\text { sex }\end{array}$ & $\begin{array}{l}\text { Age } \\
\text { (years) }\end{array}$ & $\begin{array}{l}\text { Calcium: } \\
\text { preop/postop } \\
\text { (mg/dl) }\end{array}$ & $\begin{array}{l}\text { PTH } \\
(\mathrm{pg} / \mathrm{ml})\end{array}$ & $\begin{array}{l}\text { Calcitonin } \\
(\mathrm{pg} / \mathrm{ml})\end{array}$ & $\begin{array}{l}\text { RET } \\
\text { mutation } \\
\text { (codon, } \\
\text { genotype) }\end{array}$ & $\begin{array}{l}\text { Thyroid } \\
\text { histology }\end{array}$ \\
\hline $1 / \mathrm{F}$ & 2 & $9.7 / 9.5$ & 82 & 13.8 & c620CGC & $\mathrm{CCH}$ \\
\hline $2 / \mathrm{M}$ & 4 & $9.0 / 8.9$ & 27 & ND & c618AGC & Normal \\
\hline $3 / \mathrm{F}$ & 5 & $10.2 / 9.7$ & 22 & ND & c618AGC & $\mathrm{CCH}$ \\
\hline $4 / F$ & 5 & $9.4 / 9.6$ & 36 & 13.0 & c618AGC & $\mathrm{CCH}$ \\
\hline $5 / \mathrm{M}$ & 6 & $10.2 / 9.4$ & ND & 13.0 & c618AGC & $\mathrm{CCH}$ \\
\hline $6 / \mathrm{M}$ & 9 & $9.4 / 9.6$ & 32 & 13.9 & c620TGG & $\mathrm{CCH}$ \\
\hline $7 / \mathrm{F}$ & 9 & $9.4 / 7.9$ & 86 & ND & c618AGC & $\mathrm{CCH}$ \\
\hline $8 / \mathrm{F}$ & 10 & $9.6 / 9.0$ & 38 & 13.0 & c618AGC & $\mathrm{CCH}$ \\
\hline $9 / \mathrm{F}$ & 10 & $9.3 / 9.1$ & 27 & ND & c618AGC & $\mathrm{CCH}$ \\
\hline $10 / \mathrm{M}$ & 11 & $9.6 / 9.7$ & 20 & 6.8 & c620TGG & $\mathrm{CCH}$ \\
\hline $11 / \mathrm{F}$ & 12 & $10.0 / 9.4$ & 34 & 17.0 & c618AGC & MTC \\
\hline
\end{tabular}

$\mathrm{PTH}$, serum parathyroid hormone (intact); ND, not done; $\mathrm{CCH}, \mathrm{C}$ cell hyperplasia; MTC, medullary thyroid carcinoma.



Fig. 1. DGGE analysis of PCR-amplified fragments representing the 3 RET mutations occurring among the 11 children at Cys codons 618 and 620 in exon 10 of the RET proto-oncogene with normal sequenced controls. Single base substitution and corresponding codon relative to the $R E T$ coding sequence are as indicated. Codons are numbered from the transcription start site as defined by Kwok et al. [19] and Itoh et al. [18] Note the unique and clearly distinguishable banding pattern for each mutation and high resolving power of the DGGE mutation detection system.

\section{Biochemical Testing}

There was no biochemical evidence of hypercalcemia in any of the 11 children. Two patients had an elevated parathyroid hormone (PTH) concentration despite a normal serum calcium determination. Preoperative baseline peripheral calcitonin levels were all within the ranges of normal (females $<17 \mathrm{pg} / \mathrm{ml}$; males $<26$ $\mathrm{pg} / \mathrm{ml}$ ) in each case. Postoperative baseline and stimulated calcitonin levels were normal in each of the six children tested to date.

\section{Operative Strategy and Histologic Findings}

All 11 children underwent a total thyroidectomy performed according to the method of Crile. During the operation, resected thyroid glands were thoroughly palpated and meticulously sectioned vertically and horizontally in search of gross, macroscopic MTC with particular attention directed to the upper two-thirds

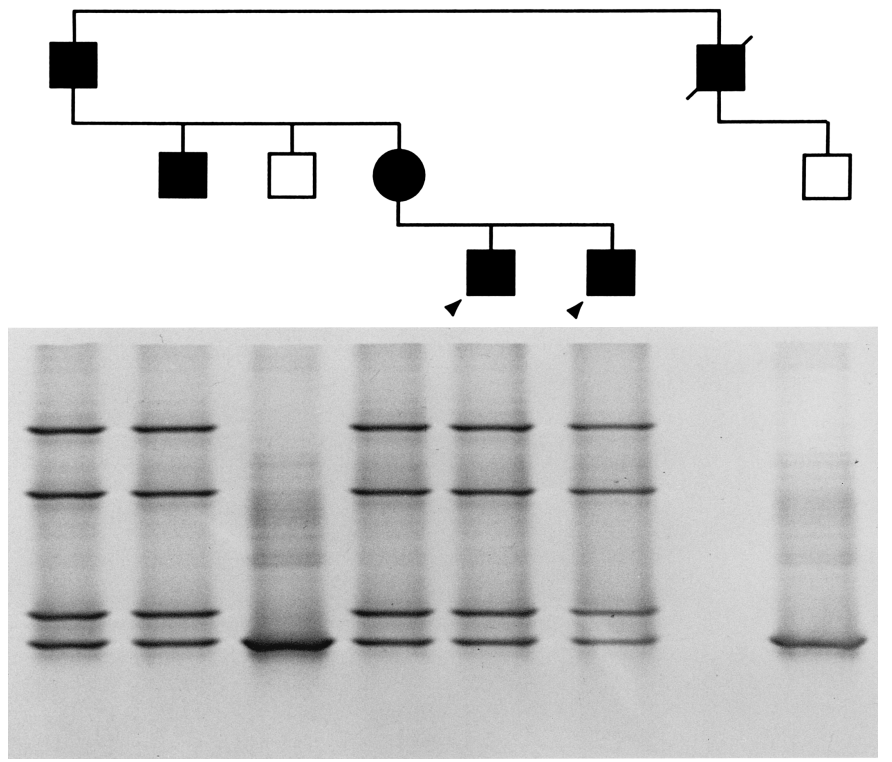

Fig. 2. Pedigree and DGGE gel analysis of $R E T$ exon 10 from a family with MEN-IIa. Closed symbols indicate patients with MEN-IIa. Unaffected individuals are indicated by the open symbols. Note the multiple banding pattern in affected members, reflecting the heterozygous missense change. Unaffected subjects show a single band, representing homozygous, wild-type sequence. Direct DNA sequencing (not shown) revealed a TGC $\rightarrow$ TGG base substitution at nucleotide 2055 , a previously unreported MEN-IIa mutation. Arrowheads, children undergoing prophylactic thyroidectomy following genetic diagnosis.

poles of each lobe, posteriorly. In each case, gross disease in the thyroid or central nodal compartment was not present, and therefore central dissections for occult metastases were deemed unnecessary. Upon histopathologic examination of the thyroid specimen, nine children had $\mathrm{C}$ cell hyperplasia $(\mathrm{CCH})$, one child (age 12 years) had medullary carcinoma, and the remaining patient (age 4 years) had normal microscopic findings. In three cases, detailed sectioning and immunohistochemical staining of the gland for calcitonin was required to identify the abnormal focus. All cases were independently reviewed by two pathologists at separate institutions. Identified parathyroid glands were grossly unremarkable in all of the children (including the two patients with an elevated PTH preoperatively) and therefore carefully dissected for in situ preservation. A parathyroid biopsy was done on three glands intraoperatively to confirm their identification. All were histologically normal. Two children underwent transplantation of a single parathyroid gland into a sternocleidomastoid muscle.

\section{Postoperative Course}

Of the 11 children, 10 maintained normocalcemia throughout their operative course. A single child, age 9 years, required transient calcium and vitamin $\mathrm{D}$ replacement. Of the 10 children with a normal calcium, 5 were discharged within 24 hours after operation. Early discharge in the remaining 5 patients was compromised by postanesthesia nausea and vomiting, which prolonged hospitalization up to 36 hours. There were no wound or recurrent nerve complications. 


\section{Discussion}

The RET proto-oncogene encodes a 1114 amino acid protein resembling a transmembrane receptor with tyrosine kinase activity $[18,19]$. Structurally, the protein consists of a signal sequence, an extracellular domain harboring a cysteine-rich region and sequence homologous to the cadherins, a hydrophobic transmembrane domain, and an intracellular tyrosine kinase domain. It is predicted that $R E T$ encodes a receptor for a presently unknown growth factor ligand. Transcription of c-RET mRNA is found in normal human thyroid $C$ cells [20] and preferentially in tumors derived from neural crest, including the MEN-II tumors, MTC, and pheochromocytoma [21, 22]. The parathyroid gland, also affected in MEN-IIa, is not a neural crest derivative but arises from the endoderm of the posterior branchial arches, which strongly express $R E T$ during embryogenesis [23]. It provides the common developmental link between the thyroid, adrenal, and parathyroid tissues involved in MEN-IIa.

Parathyroid disease occurs in approximately $10 \%$ to $20 \%$ of patients with MEN-IIa [3, 13, 14]. Unlike the HPT of MEN type I (MEN-I), however, parathyroid disease when present in MENIIa tends not to involve all four glands. Therefore adequate treatment has traditionally been achieved by resection limited to the abnormally enlarged gland(s). The basis for the highly variable expression of HPT in the MEN-IIa syndrome between kindreds is unknown (vide infra). To date, parathyroid disease has been documented in two of the four MEN-IIa kindreds in this study at low incidences of $12 \%$ and $4 \%$, respectively. The PTH elevation in two of the children preoperatively remains unexplained, as there was no biochemical evidence of hypercalcemia or grossly enlarged parathyroid glands by careful inspection in either case. Therefore parathyroid resection was deemed unwarranted, and routine parathyroid biopsy of macroscopically unremarkable glands was not performed in any of the children as to avoid iatrogenic hypoparathyroidism. Likewise, in a report by Wells and colleagues [12] there was no indication of parathyroid pathology in 13 genetically positive children, although treatment consisted of total parathyroidectomy and autotransplantation. Furthermore, we [3] and others [13] have shown in previous studies that children subjected to early thyroidectomy as a result of prospective (pentagastrin) screening for $\mathrm{CCH}$ showed no evidence of parathyroid hyperplasia at the time of thyroid operation or during a follow-up period of 10 years. For these reasons, it seems that parathyroid gland preservation, rather than resection, is appropriate and sufficient for children undergoing prophylactic treatment for MEN-IIa.

An initial study correlating RET genotype and disease phenotype in 54 MEN-IIa families with diverse mutations suggests that the CGC mutation at codon 634 in exon 11, which produces a cysteine to arginine amino acid substitution, is strongly predictive of parathyroid disease $(p=0.000008)$ [10]. Mulligan et al. [10] reported a high incidence $(73 \%)$ of families with MTC and parathyroid disease specifically had the TGC $\rightarrow$ GCG mutation at codon 634 . The basis of this specificity is unknown but may reflect a variance in sensitivity to the dosage of $R E T$ required to trigger hyperplasia in the respective $\mathrm{C}$ cell, adrenal, and parathyroid tissues. Obviously, although RET expression studies are needed to examine this model, it may be that any MEN-IIa RET mutation is sufficient to induce $\mathrm{CCH}$ in the thyroid gland, whereas a higher threshold and level of RET expression, as possibly conferred by

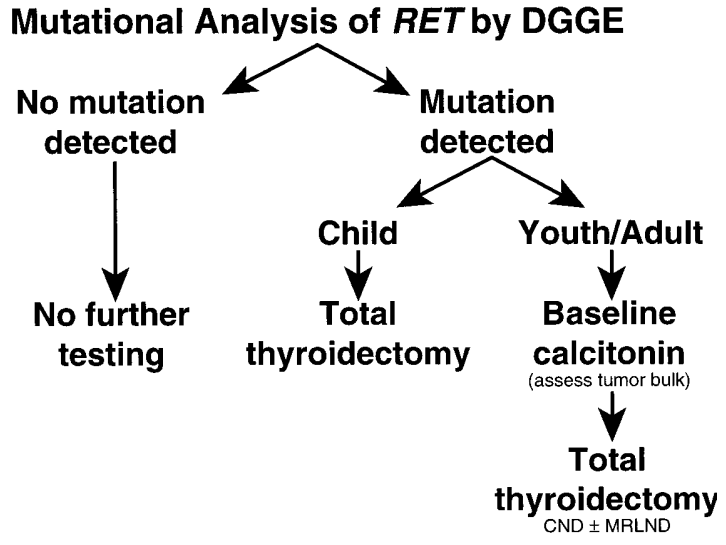

Fig. 3. Management of patients with MEN-IIa after genetic diagnosis (see text).

Cys634Arg mutation, is necessary to affect the parathyroid cell. However, the correlation between this mutation and parathyroid involvement is not absolute, and therefore all patients with hereditary MTC regardless of RET genotype must be screened annually for hyperparathyroidism (HPT). Furthermore, the presence of the CGC c634 genotype segregating within a family cannot predict the occurrence of parathyroid disease in any given affected member. For these reasons, it appears that the genetics of HPT in MEN-IIa is more complex than that of the $\mathrm{C}$ cell disease; and an individualized, rather than uniform, approach to operative management of the parathyroid glands is indicated. None of the 11 children in the present study had the CGC c634 mutation. Clarification of whether young children with the c634 genotype are ultimately at a greater risk for harboring or developing parathyroid adenomas following prophylactic thyroidectomy awaits dedicated studies of this patient subgroup.

It may be argued that total parathyroidectomy and autotransplantation are routinely necessary to ensure adequacy of the central compartment dissection in these young children. However, operative strategies employed to deal with possible nodal spread cannot by definition be designated "prophylactic" and should not be recommended in the asymptomatic setting. Young children with MEN-IIa predicted to have histologically normal thyroid glands or premalignant $\mathrm{CCH}$ do not require nodal explorations with the attendent potential morbidity. More extensive dissections should be reserved for patients with evidence of macroscopic thyroid tumor or obvious nodal metastases. The oldest of the 11 children in this series (age 12 years) had histologic evidence of malignant conversion to microscopic MTC and therefore in the strictest sense had surpassed "prophylactic" treatment. Postoperative stimulated calcitonin levels at 30 months remain undetectable. Fortunately, the capability to diagnose MEN-IIa genetically should allow earlier thyroid resection, prior to the development of any biochemical and histologic abnormalities.

Our current strategy for the management of the thyroid $\mathrm{C}$ cell disease and parathyroids in patients at risk for MEN-IIa is shown in Figure 3. This approach is cost-effective and results in the least morbidity to patients. As indicated, DNA analysis by direct mutation detection using DGGE is the first-line diagnostic tool for evaluating MEN-IIa and performed in lieu of conventional calcitonin screening. Overall, given the autosomal dominant na- 
ture of disease transmission, it can be anticipated that approximately one-half of the biologic children from an affected parent will have the mutation, males and females being equally predisposed. Because of the predictive power and high resolution of our DGGE technique, patients who do not carry a RET mutation are confidently excluded, along with their descendants, from the screening process without any further evaluation. Management of those individuals testing genetically positive is determined by age, manner of presentation, and gross findings of the thyroid and parathyroid glands at the time of operation. Generally, asymptomatic children can undergo thyroid operation without biochemical evaluation of their $\mathrm{C}$ cell abnormality, and we have therefore abandoned preoperative pentagastrin screening. At surgery, the resected thyroid specimen is carefully sectioned and inspected for macroscopic tumor (understanding that the disease may be of millimeter size). If present, a central compartment dissection for occult nodal disease including thymectomy is considered. If absent, operation is limited to a total thyroidectomy. In this study, macroscopic disease was not present in any of the 11 children, and therefore operation consisted in thyroid resection alone.

Parathyroid activity is routinely determined preoperatively in all patients including young children by measuring PTH, serum calcium, or both. A normal calcium value obviates the need to search exhaustively for all four parathyroid glands if they cannot be readily identified without extensive dissection. In this scenario, parathyroid resection with transplantation to a sternocleidomastoid rather than forearm muscle is performed and is reserved for those cases in which the vascular supply to a normal gland appears tenuous. Parathyroid glands preserved in situ may be tagged with metal clips to indicate their location.

Given the age-dependent penetrance of MTC in MEN-II, older children and adults who are genetically positive are at risk for more advanced disease. Therefore a fasting baseline calcitonin level is determined in these groups to assess tumor bulk and the need for a metastatic evaluation as well as to plan operative strategy. However, at no time has calcitonin testing been undertaken to confirm results of our DNA analysis. Of course, biochemical screening must continue in the few patients at risk for MEN-IIa from clearly established families in whom the RET mutation has not yet been identified.

We have initiated genetic screening in children as early as infancy. Early diagnosis allows parents to plan for timely, elective (prophylactic) operation and relieves them of undue concern for children found to be nongene carriers. It is our recommendation that total thyroidectomy be undertaken by age 5 years in children who have a MEN-IIa RET mutation. The results of this study have shown that $\mathrm{CCH}$ is present as early as 2 years of age, and indeed MTC has been reported in a child with MEN-IIa at age 2.8 years [24]. Others have suggested that provocative pentagastrin screening be continued in children testing genetically positive so as to defer operation until the age of biochemical conversion [25]. Proponents of this strategy maintain that thyroidectomy is better tolerated and technically easier in the older child or adolescent. We do not espouse this approach as it does not alter the inevitability of operative treatment and contributes unnecessarily to patient morbidity, parental anxiety, and medical costs. Indeed, it has been our experience that children as young as 2 years of age can undergo thyroidectomy with no complications and far less subjective trauma than do adolescents. Moreover, thyroidectomy in the young child is no more technically challenging than in the adult, especially in the hands of an experienced thyroid surgeon. Furthermore, early thyroid operation is more likely to be truly "prophylactic" in nature and curative. Finally, there appears to be an overlap in the absolute calcitonin levels, which correspond to disease progression from $\mathrm{CCH}$ to MTC and vary with the calcitonin assaying system employed. This situation further increases the uncertainty and risks involved with postponing definitive surgery until more impressive and "definitive" biochemical abnormalities are realized.

As shown in the current study, early operation after genetic diagnosis alone occasionally results in removal of histologically normal thyroid glands. This possibility should be anticipated and considered desirable for the operative treatment initiated for prophylaxis, as the age of disease onset (penetrance) varies in children. Unremarkable histology occurred in a single child in this study age 4 years with Hirschsprung's disease, a phenotypic marker of MEN-IIa that supported the genetic findings. In three children, detailed sectioning of the gland and immunohistochemical staining for calcitonin were required to uncover the disease focus, attesting to the importance of careful specimen sampling and the greater sensitivity of genetic testing for detecting an affected status. Various DNA-based techniques have emerged to identify RET mutations. Unlike other methods, the DGGE approach we have employed has been acknowledged by others as capable of detecting virtually $100 \%$ of mutations [26, 27]. Abnormal findings identified by DGGE are routinely confirmed by direct DNA sequencing and restriction fragment length polymorphism (RFLP) analysis. Discordance between results has not been observed.

The frequency of postoperative follow-up screening by calcitonin testing in children undergoing preventive thyroidectomy is not yet defined, although intuitively it will be less stringent than that for macroscopic disease. If completeness of the thyroid resection can be ensured, "recurrence" of MTC following removal of a gland containing the premalignant $\mathrm{CCH}$ alone or normal histology would be unexpected. Of course, lifelong biochemical surveillance for development of HPT or adrenal pheochromocytoma regardless of the RET genotype is indicated.

In conclusion, routine parathyroidectomy during prophylactic thyroidectomy in children with MEN-IIa does not appear necessary. Long-term follow-up studies are needed to better determine the occurrence of HPT after preventive surgery prior to recommending a radical approach, such as four-gland resection and heterotopic reimplantation. It appears that more conservative measures are desirable in these young children to minimize any potential morbidity with prophylactic thyroidectomy, including that associated with total parathyroidectomy and autotransplantation.

\section{Résumé}

L'identification de la mutation germline dans le proto-oncogène RET, prédisposant au syndrome de néoplasie endocrine multiple (MEN) 2a, permet une approche diagnostique basée sur l'étude de l'ADN et il peut être proposé alors une thyroïdectomie à titre prophylactique chez l'enfant génétiquement positif. Bien que la thyroïdectomie totale soit le traitement de choix pour la maladie des cellules $\mathrm{C}$, la nécessité d'y associer une parathyroïdectomie totale systématique suivie d'autotransplantation, déjà décrite chez les enfants asymptomatiques, est tout à fait discutable, compte 
tenu de la prévalence basse de l'hyperparathyroïdie dans le MEN 2a (10-20\%). Trente-six enfants à risque pour la maladie car faisant partie de la proche famille de quatre patients MEN 2a (âgés de 1 mois à 12 ans), ont eu une analyse mutationelle, réalisée par la technique d'électrophorèse sur gel dénaturant basée sur une PCR hypersensible. Les concentrations de calcium dans la parathyroïde et/ou le sérum ont été déterminées en préopératoire. On a trouvé la mutation MEN 2a chez 18 des 36 enfants à risque, dont 11 ont eu une thyroïdectomie à titre prophylactique entre l'âge de 2 à 12 ans (moyenne $=7.5$ ans). Dans chaque cas, il n'y avait aucune preuve biochimique d'hypercalcémie en préopératoire. Toutes les glandes parathyroïdes ont été identifiées et apparaissaient macroscopiquement normales à l'exploration. Les glandes ont été disséquées et laissées in situ. En postopératoire, on a maintenu la normocalcémie chez 10 des 11 enfants, ce qui a permis de les laisser sortir de l'hôpital entre 24-36 heures après l'opération. La thyroïde réséquée contenaient une hyperplasie des cellules $\mathrm{C}$ chez neuf, un cancer médullaire chez un alors que l'histologie était normale chez le dernier. Nous concluons qu'une alternative à la parathyroïdectomie systématique peut être proposée dans le traitement prophylactique du syndrome MEN 2a. La conservation parathyroïdienne in situ peut être accomplie avec sécurité sans compromettre le caractère complet de la résection de la thyroïde. Cette approche conservatrice épargne le patient de la morbidité potentielle associée à la parathyrö̈dectomie totale suivie de l'autotransplantation.

\section{Resumen}

La identificación de mutaciones en el proto-oncogen RET predisponente de la neoplasia endocrina múltiple tipo 2 a (NEM 2a) ha permitido un aproche diagnóstico y terapéutico basado en DNA mediante tiroidectomía profiláctica en niños que aparezcan positivos en la prueba genética. Aunque la tiroidectomía total es la operación aceptada para la enfermedad de células C, aparece cuestionable la necesidad de paratiroidectomía total con auto trasplante rutinario como ha sido previamente descrito en estos niños asintomáticos, en especial si se tiene en cuenta la baja incidencia de hiperparatiroidismo en el NEM-2a (10-20\%). Treinta y seis niños (edad 1 mes- 12 años) parientes de cuatro pacientes con NEM-2a en riesgo de desarrollar la enfermedad fueron sometidos a la prueba genética. Se practicó análisis mutacional utilizando una técnica altamente sensible de electroforesis, se hicieron determinaciones preoperatorias de las concentraciones de hormona paratiroidea y/o calcio. Dieciocho de 36 niños en riesgo resultaron con la mutación NEM-2a, 11 de los cuales han sido sometidos a tiroidectomía profiláctica a las edades entre 2 y 12 años (media 7.5 años). En cada caso no hubo evidencia preoperatoria de hipercalcemia y todas las paratiroides fueron identificadas como macroscópicamente normales durante la exploración operatoria. Las glándulas fueron cuidadosamente identificadas y dejadas in situ. En el postoperatorio 10 de 11 niños mantuvieron normocalcemia, lo cual permitió su egreso a las 24-36 horas. Las glándulas tiroides resecadas exhibieron hiperplasia de células $\mathrm{C}$ en 9 casos, carcinoma medular en 1 e histología normal en 1. Nuestra conclusión es que es deseable una alternativa a la paratiroidectomía rutinaria en el tratamiento profiláctico del NEM-2a. La preservación paratiroidea in situ puede ser lograda exitosamente sin comprometer la totalidad de la resección tiroidea. Este aproche conservador evita la morbilidad asociada con la paratiroidectomía total con autotrasplante.

\section{Acknowledgments}

R.A.D. is a recipient of the American College of Surgeons Faculty Award. This study was supported by grants to R.A.D. from the National Institutes of Health (1K08DK02176-03) and the American Cancer Society (VM-73A).

\section{References}

1. Mulligan, L.M., Kwok, J.B.J., Healey, C.S., et al.: Germ-line mutations of the RET proto-oncogene in multiple endocrine neoplasia type 2a. Nature 363:458, 1993

2. Donis-Keller, H., Dou, S., Chi, D., et al.: Mutations in the RET proto-oncogene are associated with MEN 2a and FMTC. Hum. Mol. Genet. 2:851, 1993

3. Decker, R.: Long-term follow-up of a large North American with multiple endocrine neoplasia type 2a. Surgery 112:1066, 1992

4. Schimke, R.N.: Genetic aspects of multiple endocrine neoplasia. Annu. Rev. Med. 35:25, 1984

5. Komminoth, P., Kunz, E.K., Matias-Guiu, X., et al.: Analysis of RET protooncogene point mutations distinguishes heritable from nonheritable medullary thyroid carcinomas. Cancer 76:479, 1995

6. Schuffenecker, I., Billaud, M., Calender, A., et al.: RET protooncogene mutations in French MEN 2a and FMTC families. Hum. Mol. Genet. 3:1939, 1994

7. Xue, F., Hong, Y., Maurer, L., et al.: Germline RET mutations in MEN 2a and FMTC and their detection by simple DNA diagnostic tests. Hum. Mol. Genet. 3:635, 1994

8. Bolino, A., Schuffenecker, I., Luo, Y., et al.: RET mutations in exons 13 and 14 of FMTC patients. Oncogene 10:2415, 1995

9. Eng, C., Smith, D.P., Mulligan, L.M., et al.: A novel point mutation in the tyrosine kinase domain of the RET proto-oncogene in sporadic medullary thyroid carcinoma and in a family with FMTC. Oncogene 10:509, 1995

10. Mulligan, L., Eng, C., Healey, C., et al.: Specific mutations of the RET proto-oncogene are related to disease phenotype in MEN 2a and FMTC. Nat. Genet. 6:70, 1994

11. Decker, R.A., Peacock, M.L., Borst, M.J., Sweet, J.D., Thompson, N.W.: Progress in genetic screening of multiple endocrine neoplasia type 2a: is calcitonin testing obsolete? Surgery 118:257, 1995

12. Wells, S.A., Chi, D.D., Toshima, K., et al.: Predictive DNA testing and prophylactic thyroidectomy in patients at risk for multiple endocrine neoplasia type 2a. Ann. Surg. 220:237, 1994

13. Gagel, R.F., Tashjian, A.H., Cummings, T., et al.: The clinical outcome of prospective screening for multiple endocrine neoplasia type 2a. N. Engl. J. Med. 318:478, 1988

14. Thakker, R.V., Ponder, B.A.J.: Multiple endocrine neoplasia. Clinical Endocrinology and Metabolism (Vol. 2), M.C. Sheppard, editor. Baillière Tindall, London, 1988, p. 1031

15. Decker, R.A.: Expression of papillary thyroid carcinoma in multiple endocrine neoplasia type 2a. Surgery 114:1059, 1993

16. Peacock, M.L., Borst, M.J., Sweet, J.D., Decker, R.A.: Detection of RET mutations in multiple endocrine neoplasia type $2 \mathrm{a}$ and familial medullary thyroid carcinoma by denaturing gradient gel electrophoresis. Hum. Mutat. 7:100-104, 1996

17. Lerman, L., Silverstein, K.: Computational simulation of DNA melting and its application to denaturing gradient gel electrophoresis. Methods Enzymol. 155:482, 1987

18. Itoh, F., Ishizaka, Y., Tahira, T., et al.: Identification and analysis of the ret proto-oncogene promoter region in neuroblastoma cell lines and medullary thyroid carcinoma from MEN 2a patients. Oncogene 7:1201, 1992

19. Kwok, J.B.J., Gardner, E., Warner, J.P., Ponder, B.A.J., Mulligan, 
L.M.: Structural analysis of the human RET proto-oncogene using exon trapping. Oncogene 8:2575, 1993

20. Fabien, N., Paulin, C., Santoro, M., et al.: The RET proto-oncogene is expressed in normal human parafollicular thyroid cells. Int. J. Oncol. 4:623, 1994

21. Santoro, M., Rosati, R., Grieco, M., et al.: The RET proto-oncogene is consistently expressed in human pheochromocytomas and thyroid medullary carcinomas. Oncogene 5:1595, 1990

22. Nakamura, T., Ishizaka, Y., Nagao, H.M., Ishikawa, T.: Expression of the RET proto-oncogene product in human normal and neoplastic tissues of neural crest origin. J. Pathol. 172:255, 1994

23. Smith, D.P., Eng, C., Ponder, B.A.J.: Mutations of the RET proto- oncogene in the multiple endocrine neoplasia type 2 syndromes and Hirschsprung's disease. J. Cell Sci. 18:43, 1994

24. Telander, R.L., Zimmerman, D., Sizemore, G.W., van Heerden, J.A. Grant, C.S.: Medullary thyroid carcinoma: results of early detection and surgery. Arch. Surg. 124:841, 1989

25. Lips, C.J.M., Landsvater, R.M., Hoppener, J., et al.: Clinical screening as compared with DNA analysis in families with multiple endocrine neopalsia type 2a. N. Engl. J. Med. 331:828, 1994

26. Cotton, R.G.H., Malcolm, A.D.B.: Mutation detection. Nature 353: 582,1991

27. Dianzani, I., Camaschella, C., Ponzone, A., Cotton, R.G.H.: Dilemmas and progress in mutation detection. TIG 9: 1993.

\section{Invited Commentary}

\author{
J.F. Moley, M.D.
}

Department of Surgery, Washington University School of Medicine, St. Louis, Missouri, U.S.A.

Identification of RET gene mutations in patients at risk for the development of the hereditary forms of medullary thyroid carcinoma (MTC) has simplified management and expanded the scope of indications for surgical intervention. Patients who carry this mutation can be offered operation at a young age, hopefully at a point when the cancer has not yet developed or spread. Those who are found not to have inherited the mutation are spared further genetic and biochemical screening. This achievement marks a new paradigm in surgery - the recommendation that operation be performed based on the result of a genetic test. As with the decision to perform any surgical procedure, meticulous preparation and detailed discussion with the patient and family must precede the final recommendation. At our institution, genetic testing is repeated and confirmed on a separately drawn blood sample, and the patient and family are involved in preoperative discussions with genetic counselors as well as the surgical team.

This paper by Decker et al. adds to the growing number of reports of surgical intervention in patients who have inherited a multiple endocrine neoplasia (MEN) type IIa RET gene mutation. In this contribution, the authors stress their approach to the parathyroid glands. At the time of thyroidectomy, they biopsy and mark each parathyroid gland with a surgical clip and leave the glands in situ. This approach is similar to that reported by other groups performing thyroidectomy in MEN-IIa gene carriers [1-3]. The approach contrasts with the practice at our institution, which is to perform total thyroidectomy, central node dissection, and total parathyroidectomy with autotransplantation of a portion of the parathyroid tissue into the muscle of the nondominant forearm, and viable freezing of the remaining tissue [4]. We continue to prefer this approach for the following reasons. First, patients with MEN-IIa are at risk for the development of hyperparathyroidism. If a patient subsequently develops hyperparathyroidism, localization of the hyperfunctioning tissue is simpler if the parathyroid tissue is in the arm. Operation to reduce parathyroid tissue is carried out under local anesthesia as an outpatient, obviating the risk of redo neck exploration. Decker et al. point out that the overall incidence of hyperparathyroidism is low, and that patient selection for parathyroidectomy might be guided by the type of genetic mutation a patient has. At the present time, the risk of hyperparathyroidism in patients with different RET gene mutations is unclear. The Cys634Arg mutation was most strongly associated with the presence of hyperparathyroidism in one study correlating genotype with phenotype [5]. In that study, however, criteria for diagnosis of hyperparathyroidism were not specified. In addition, there was a preponderance of kindreds (24 of 54 evaluable kindreds) affected by a Cys634Arg mutation. Before using genotype data to determine whether to transplant the parathyroids, the data from this important initial study should be confirmed by other groups. The risk of hyperparathyroidism in MEN-IIa gene carriers following preventive thyroidectomy can only be determined by follow-up over the lifetime of the patients.

Second, routine removal of the parathyroids ensures that an adequate central node dissection can be done without jeopardizing parathyroid function. Decker and colleagues state that lymph node metastasis is unlikely in patients who have inherited MENIIa mutations who undergo preventive thyroidectomy. We have found that metastases do occur in these patients. In our experience, histologic evidence of metastatic involvement of central nodes was reported by the pathologists in 2 of 44 cases of preventive thyroidectomy in MEN-IIa gene carriers. In one of these patients there was no evidence of tumor on gross sectioning of the gland. In addition, the fact that routine histologic examination (hematoxylin and eosin staining) fails to demonstrate metastatic MTC does not exclude the possibility that occult foci were removed. Of 50 patients with recurrent hypercalcitoninemia after thyroidectomy with node removal for MTC followed by our group, five patients had no histologic evidence of node involvement at first operation. All five were found to have metastatic involvement of residual neck nodes at an operation done years later. In two patients from our series of patients with recurrent hypercalcitoninemia following thyroidectomy for MTC, reoperation with excision of cervical nodes resulted in marked reduction in stimulated calcitonin levels even though routine pathologic examination revealed no evidence of metastatic nodal involvement. This suggests that in some cases metastatic foci may not be detected by routine histologic examination.

Medullary thyroid cancer is an indolent disease, and recurrences may not be apparent for decades. The recurrence rate of MTC following preventive thyroidectomy in MEN-IIa gene carriers is not known and will not be known until these patients have 
been followed for many years. Central node dissection is safe and simple to perform; however, the parathyroids are closely associated with nodes draining the thyroid, and parathyroid blood supply may be damaged in the process of removing these nodes. Parathyroidectomy and autotransplantation ensures preservation of parathyroid function.

In our series of 44 preventive thyroidectomies with central node dissection in MEN-IIa gene carriers, parathyroidectomy with autotransplantation has been carried out safely. In all patients, there is evidence of good graft function, and only one patient (who has a functioning autograft) still requires calcium supplementation. We therefore continue to favor routine parathyroidectomy and autotransplantation as a part of all primary operations for MTC, including those done based on the result of a genetic test, in a preventive setting.

\section{References}

1. Lips, C.J.M., Landsvater, R.M., Hoppener, J.W.M., et al.: Clinical screening as compared with DNA analysis in families with multiple endocrine neoplasia type 2a. N. Engl. J. Med. 331:828, 1994

2. Frilling, A., Dralle, H., Eng, C., et al.: Presymptomatic DNA screening in families with multiple endocrine neoplasia type 2 and familial medullary thyroid carcinoma. Surgery 118:1099, 1995

3. Pacini, F., Romei, C., Miccoli, P., et al.: Early treatment of hereditary medullary thyroid cancer after attribution of multiple endocrine neoplasia type 2 gene carrier status by screening for RET gene mutations. Surgery 118:1031, 1995

4. Wells, S.A., Chi, D.D., Toshima, K., et al.: Predictive DNA testing and prophylactic thyroidectomy in patients at risk for multiple endocrine neoplasia type 2A. Ann. Surg. 220:237, 1994

5. Mulligan, L.M., Eng, C., Healey, C.S., et al.: Specific mutations of the RET proto-oncogene are related to disease phenotype in MEN 2a and FMTC. Nat. Genet. 6:70, 1994 